\title{
Earth-Bound Study as a Post-Critical Response to the Corona-Crisis
}

\author{
Joris Vlieghe (KU Leuven) and Piotr Zamojski (University of Gdańsk)
}

\begin{abstract}
:
In this paper, we want to flesh out what a post-critical way of dealing with the pandemic we face today could consist of. In the first part, we give an account of the current situation in terms of the remarkably ambiguous experience brought about by the intrusion of the COVID-19 virus, which has confronted us with a threat that is radically transcendent and immanent at the same time. In the second part, we go deeper into specific insights that have come about in the wake of this crisis, showing that these insights can be taken in two directions. We can try and align them with what we already know, or we can try to take seriously the unforeseen novelty of the situation. However, in the third part, we argue that we can still answer in a different, more fundamental and truly educational manner. This consists of "being taught" by the virus, thereby re-establishing our relation with the world and its human and non-human "indwellers". This comes down to reorienting our educational endeavours towards earth-bound study practices, with a view to coming up with new answers to the "old" question of how to live well together.
\end{abstract}

Keywords:

COVID-19 crisis; Latour; post-critical pedagogy; study practices

It is rare for the thoughts of people from all around the world to be focused on one and the same issue, yet this has happened. Without fear of doubt, we can safely say that the issue of the COVID-19 pandemic is literally on everybody's mind; and although we agree with the criticism that this subject matter is fair game for academics in these extraordinary circumstances (as Carusi et al., 2020, have recently declared), we believe that it would be virtually impossible to avoid thinking about this matter altogether, or to refrain from exchanging and discussing our views - as we are used to doing. It is in this spirit that we are contributing to this issue of on_education. However, we certainly do not want to be part of the academic frenzy of immediately responding by writing books on this issue, seizing the opportunity to apply for research grants, etc. To be honest, we are far from sure that this is the right time to write this intervention, fearing that what we say might be judged as a rushed reflection. Yet we have decided to make these preliminary remarks on the corona-crisis. This is because up to now, we have had the impression that the standard response in the field of education and educational philosophy has mainly been a "critical" one. By this, we mean that the only educational answer we seem to have been able to give, thus far, has consisted of taking a position showing "what is really happening", because most people seem not to realize (yet) the true meaning of our current predicament. They seem to have incorrect representations about the situation, and they are not sufficiently alarmed or ready to take action, etc. What we want to argue, in this piece, is that the situation we are in is a commonly shared experience, the actuality and acuteness of which don't need to be revealed. Hence, we want to argue that it is possible to give a more affirmative and postcritical response (see Hodgson et al., 2017), which is educational in a strong sense, meaning that today (maybe more than ever), we can re-examine and revise the value of particular pedagogical practices in the face of the COVID19 crisis. What we suggest is that such a fully positive answer to the disheartening situation we are in may consist of earth-bound study practices. Nevertheless, in order to develop such a response, we first need to say a few words about a particular tension that is present in the contemporary situation, in order to make it productive for a post-critical approach.

1. Disruptive Immanency. The Doubleness of the Current Situation

We want to start our argument by drawing attention to a specific tension that makes today's exigency so characteristic. On the one hand, what we face is an event in the strongest sense of this word. There was a time before and there will be a time after the intrusion of this nefarious virus. Even though, at first sight, the heart of the matter is so obvious that it does not need much discussion (a deadly virus unexpectedly showing up, transmitted from human to human, thus infecting people all around the world), what we are experiencing is unprecedented and remains, to a large extent, something whose meaning is very difficult to fathom right now. Apart from the fact that there is much we do not know about the virus (in terms of what the life sciences still need to discover), it is the newness of what 
we have started experiencing on a daily basis that has made such an impact. Many of us have, for the first time in our lives, been confronted with the most severe biopolitical arrangements. We have been forced to stay within the confines of our homes; to accept serious limits to our freedom of movement; to do without face-to-face meetings; and some have had to forego work, business or school. All of a sudden, it seems that thanks to this virus, we have accomplished what seemed impossible before. We have put capitalism on hold; excessive growth of world economies has finally stopped; it is now apparent that there are things that are more important than increasing our GDP; and it may even be that, as a by-product of this new arrangement, we can hope to achieve ecological goals previously believed impossible (Latour, 2020a, 2020b; Ieven \& Overwijk, 2020). Even if, today, we have come to realize that this was an unrealistic appraisal of the situation (as the economy has already begun to run as it did before, and in spite of the second wave and the new lock-down measures we are faced with today, parts of our social life have returned to normal), it cannot be denied that between February and March 2020, within a few weeks (if not days), we dramatically changed our way of life (or we at least now know that it is possible to do so). What we do not know is what marks this will leave, and which changes will remain forever. That is why it makes sense to regard the corona-crisis as an event, the impact of which could never have been predicted or foreseen. What we are witnessing today is radically new, and we are being confronted with something that, so to speak, comes from the outside.

In order for the seemingly inexorable machinery of contemporary capitalism to come to a stop, a force from the outside had to throw a spanner in the works. This is what we have seen happening, as if witnessing the advent of a radically uncompromising Otherness; something so alien that it has the strength to make us give up many of the things we hold dear, and whose intrusion has horrendous consequences (predicted mostly by science-fiction authors, but so far ignored by Western philosophy). But unlike the Other as conceived of in the wake of Levinas and Derrida, the current Otherness has effected an interruption which calls for an absolute obsession with preservation of our self-interests and lives - at all costs; i.e., we have not responded to this Otherness with gestures of hospitality. We have given up many things that seemed to be beyond question, in order to prevent the Other from entering our lives. In a way, this virus is like a comet: suddenly appearing in the skies and ready to bring ruin upon the entire planet; an out-of-this-world threat which will not submit to the laws of human society - indifferent to monetary flows, the desire to accumulate capital, and our obsession with reaching benchmarks. As a radical force of disruption, the virus has made the machine grind to a halt.

On the other hand, we are also experiencing the exact opposite, for it is also the case that this Other is not a comet at all. Instead, it clearly finds its origin and spawning grounds fully in this world, as it is global capitalism, led by the logic of growth, that has contributed to the inception and spread of this virus (Ieven \& Overwijk, 2020). Ongoing deforestation causes human settlements to be in closer proximity to the shrinking resorts of wildlife (see Gibb et al., 2020; Tollefson, 2020), and this also turns these animals into rare, luxury commodities for the wealthy, looking for new forms of excitement and ways to distinguish themselves (Ieven \& Overwijk, 2020). As a result, things hitherto hidden in the heart of darkness have come to the surface and begun to proliferate all over the planet, expedited by global supply chain networks, existing business routes, global mass tourism and all the other things that stem from our desire to move about and meet. We have also become vividly aware of our own dependency on what happens in other parts of the world. Therefore, despite the fact that the intrusion of the virus is experienced as an external interruption and that we sense that something of a different order has invaded our daily life, it is, in fact, the way we give shape to this daily life that is responsible for the occurrence and circulation of the virus. The very way in which we have organized our collective lives has created the pandemic: our habits, our movements, our cravings, the infrastructures we rely on, etc. We have, so to speak, catalysed this newness. As such, the pandemic is, through and through, an ecological phenomenon. It can only be understood against the background of a deep interconnectedness of human and non-human realities, and it shows that our doings have undesired side effects, the severity of which we simply cannot deny. We are incontrovertibly confronted with our earthly condition. We are inhabitants of a world that is not merely a stage setting, against the backdrop of which we run our human affairs; instead, the world we have messed with has responded in a most vicious manner, changing the nature of our existence and the lifestyle we have become accustomed to in the recent past (Latour, 2017, 2018). In sum, what is characteristic of the circumstances we face today is that we are being confronted by a force that radically upsets things and that is experienced as simultaneously transcendent and immanent; something new for which we could not have been prepared, yet whose mayhem is, ultimately, a result of how we have decided to lead our lives in this world. Despite its exceptionality and Otherness, it is also fully an earthly phenomenon, partly of our own making.

\section{What Has Become Clear by Now? Some Crucial Transformations of Our Status Quo}

We will return to this ambivalent mixture of transcendence and immanence in the next section, but before doing so, we firstly want to pay attention to another twofoldness of the situation we are facing, which will help in elucidating what an affirmative and educational response might consist of. This concerns, in particular, the way in which we tend to address the newness that typifies this situation. Either we try to find a firm foothold again by subsuming the new 
under the umbrella of what we already know, or we truly relate to the event in its newness, i.e., really accept that something has happened so that we can start thinking in novel ways about ourselves, others and the world. In other words, the current crisis is showing us things that should be taken into account when considering how to give shape to our future life, individually and collectively.

The first (and probably most natural) reaction consists of the many and successive attempts to understand the new from the perspective of the already known. This conforms to the spontaneous tendency to tame the new, to recognize the old within it, and hence to make the whole situation less scary and threatening, in order to domesticate it and render things predictable. In a sense, this response is understandable and unavoidable, and in view of the expertise and tools we have at our disposal, it can easily appear as fully justified, i.e., as the only and right thing to do. But, likewise, the same response could be analysed as a case-in-point of the most radical form of biopolitics (Foucault, 2004), i.e., as if, today, power has shown its true face by decreeing the most extreme disciplinary and control measures (and by making almost all of us accept the state of exception as the new normal situation out of simple fear for our lives). Either way, this is not the line of reasoning we want to follow here as, in both cases, there is nothing new to add to what we already know.

Therefore, we propose to take another perspective and focus our attention on unforeseen features, unusual challenges and new possibilities that also come with the current predicament. The most significant novelty we are experiencing today is probably the serious damage that the dominant political imagery (i.e., our liberal conception of society) has irreversibly suffered. There would be no point in trying to use freedom of choice as an argument against the requirement to wear facemasks in public places or - for that matter - against protecting the populace by mass vaccination. This is because we seem to have (most likely, collectively) come to understand that there are certain measures that need to be respected by everyone without exception in order to be effective; i.e., if individuals or a minority were to disagree and defy such measures, this would render the measures deficient. What is thus required is a logic of political reasoning that goes beyond the liberal assumption that societies are but the result of autonomous individuals who freely enter into (and, if they choose, also withdraw from) mutual relationships with other autonomous individuals (a way of thinking strongly related with the idea of the free market). No longer conforming to this imagery, it seems we have come to realize that living well together means something else. In this sense, it was most revealing to hear the British Prime Minister, Boris Johnson (at the end of his period of self-isolation after being badly infected with the virus), make a clear reference to the (in)famous claim of Margaret Thatcher: "One thing - I think - coronavirus has already proved is that there really is such a thing as society” (Johnson, 2020).
Next to this, and on a less positive note, the same challenge has brought to the surface that political decisions are also based on a logic that exceeds the most sophisticated philosophical accounts we have entertained thus far, such as viewing decision-making in terms of biopolitics. With great uncanniness, we could experience that what Agamben (1998) analysed in his Homo Sacer project bears a kernel of truth. Because the situation forces us to make decisions about who is to receive medical care and who will not (and hence forces upon us a 'live or die' decree), we clearly live under a thanatopolitical regime. To secure the health and productivity of the body of society (i.e., as in biopolitics), political decisions have to be made which involve the very life (survival) of the masses, a corollary of which may be the actual death of groups of people. Death - being a phenomenon our contemporary culture would like to repress, forget about or marginalize has not only come to the fore as a public issue, but just like all public issues these days, it has finally become subjected to public administration. Death is no longer a taboo or something that is so extra-ordinary that it escapes management. The very fact of (re)introducing death into public discourse has put this matter into the hands of governmental power in a way that is unprecedented.

Last but not least, we have also experienced how important physical presence is in the sphere of education. Although digital environments have been widely employed during lockdowns, and their user-friendliness and quality have progressively improved (by and large), one is unlikely to see any pupils, students, teachers or lecturers publicly claim that schooling (or university education) has changed for the better, and that returning to face-to-face education is a luxury we can do without. On the contrary, many of us want to go back to "normal”, i.e., to gather physically around our subject matter. Many hypotheses have been raised pertaining to the question of why online teaching seems to miss out something essential to education - e.g., that teachers do not have the right skills to use digital environments effectively; that we need a threedimensional, physical environment within which we can move and navigate and which we can literally manipulate; or that digital devices fail to transmit nonverbal communication and make it impossible to look one another in the eyes as we either have to stare at the screen or look into the camera (see Friesen, 2020). Obviously, there is much more that we are now experiencing as a result of the generalized switch to online teaching, including, e.g., the fact that in spite of the ongoing criticism raised against it, our basic attitude seems to be one of implicitly agreeing that we trust schools. However, there is no space here to develop this thread further (and to do it justice), since what we would like to address now is the matter of responding.

\section{In Search of a Properly Educational Response}

Thus far, we have been pondering the current conditions, specifically from the point of view of what is so unique and 
characteristic about them. In the first section, we pointed out that what is happening today is experienced, paradoxically, as both an event (something utterly new and unexpected; an Otherness that has seemingly been foisted upon us by a radical outside) and, simultaneously, a phenomenon, which is immanent through and through, and which needs to be considered as fully earthly. In the second section, we went on to discern two ways in which we can (and do) respond to the newness of the situation: trying to subordinate the new to answers we already have at our disposal or really facing the newness of the event, bringing to the fore novel dimensions, challenges and possibilities that have come about.

This last option could alternatively be expressed by saying that, today, we have before us the chance to learn valuable lessons from the experience of living through a pandemic. By this, we mean that we can bring to light, become conscious of and open ourselves up to important insights in a biological, societal, political, economic and psychological sense, which could too easily remain hidden. However, this cannot be the final step. As we announced in the introduction, such an approach remains, above all, a critical approach. Moreover, the fact that we could gain significant insights from the crisis does not immediately mean that this knowledge will come to matter to us and that we will really change ourselves and our ways of living. The more crucial question is, we would argue, not what we can learn from our current distress, so much as whether the virus has taught (and/or will teach) us anything. In other words, the pressing issue that we want to raise is whether we will allow ourselves to be exposed to it in a properly educational manner.

However, this would require changing our default position vis-à-vis the corona-crisis, i.e., the assumption that the virus is a threat we need to overcome and that the educational challenge consists of revealing what really matters and who we really are. This would entail ceasing to put our intellectual efforts into debunking false representations that we might have about these conditions and which stand in the way of an adequate response, but it would also necessitate stepping beyond raising consciousness in the hope of ending up being more enlightened about the situation. Rather, what is at stake is that we start fostering attention and care, i.e., investigating the world based on true interest for and a genuine attachment to it. Such a positive attitude would be fully focused on particular things in this world. Letting ourselves be taught by the virus means re-establishing our relation with the world (see Vlieghe \& Zamojski, 2019).

Therefore, we want to return to the observation we made in the first section, namely that on an experiential level, the pandemic is something completely new and also something utterly immanent. This has, at least, five major consequences. Firstly, such a view will entail us cultivating a particular sense of history or, better still, that we allow for the possibility of history in a strong meaning of that word (Swillens \& Vlieghe, 2020). If we stick to that what we already take for granted (i.e. definitions of the problems we encounter and accepted solutions to effectively overcome these problems with a view of set goals we want to reach), it could be argued that we are living in a world without real history. Even though such a (modernist) view could be called one of progress (i.e. essentially about moving forwards in time), it could also be argued that it concerns a profoundly ahistorical perspective (see Latour, 2017). We already know with a great degree of certainty and predictability what is going to happen, what we can and cannot do and expect. What occurs then does not really happen. Within such a view there are, then, two options for us today: overcoming the crisis or being doomed. What the pandemic can teach us today is that we should not give in to a logic of necessity, but that we could also embrace another way of understanding time (and the future), which allows for the radical unforeseen to take place.

This, secondly, implies that this history - in the strongest sense of the word - takes place here and now. It is also an immanent history. It needs to be made from within our entanglement with the earth and all its inhabitants. This involves a particular "reorientation”, as Bruno Latour (2018, p. 52) would call it. As we saw in the first section, we too readily regard history as a story of humans deploying their plans against the backdrop of a static, ahistorical nature - the stage setting where the story takes place, so to speak. The current circumstances, however, confront us with the falsity of this representation. Humans are but part of a story, and hence of an immanent history, where they are only one agent among many other agents, all engaged in a similar struggle to thrive on the same earth. We are part of a shared endeavour to inhabit the earth, alongside other non-human entities that are earthly inhabitants just as we are. As such, we need to reorient our focus of attention towards the world we indwell.

Thirdly, seen from this reoriented perspective, what should bother us in the first place is not a purely scientific, technological or utilitarian issue. We should refrain from just trying to (re)gain control over our lives, based on better medical knowledge of the virus and its workings. Such knowledge is, of course, important and most desirable, but it should be part of more extensive efforts to address the question of how we can live well together, i.e., how we can thrive on this earth as human and non-human indwellers that are completely intertwined with one another (Tsing, 2015). Fourthly, this means that we do not immediately move over to action, thereby affording ourselves more time. Again, this might sound bizarre as what we have learned from the virus is that we should take urgent and forceful action - preferably now rather than tomorrow. But, in line with what we said earlier, this is a completely ahistorical view. When we persist in rushing forwards, we are cut off from a real sense of time. It is only by slowing 
down that we can experience (again) that there is, in fact, time. To have a timely experience, we have to make time. Lastly, this also means that things do not necessarily have to evolve in a set way. We can still hope for possibilities which go above and beyond the most probabilistic outcomes. This, however, does not concern the naïve quasicertainty that we will eventually all find the necessary resolve. Instead, it is about making new things possible here and now; bringing hope into the present situation, based on the experience of there being no necessity hopeness (Vlieghe \& Zamojski, 2019).

We would like to conclude with the observation that these five aspects constitute, on an experiential level, what in classical educational jargon could be termed studying. As evidenced in much recent work on this particular practice, i.e., on this unique pedagogical form, which has its own intrinsic merits (e.g., Lewis, 2015; Masschelein \& Simons, 2015; Schildermans et al., 2019), study involves more than just gaining knowledge and skills, and it comprises more than just doing research and engaging in scientifically controlled investigations. Study is more than a safe, private and uncommitted process of accumulating insights in the pursuit of a more powerful control over our own lives and the world. Surely, gaining insight in a methodical way and solving problems are important dimensions of studying. There is no point in denying this. But more importantly, study - understood as a unique pedagogical form - also involves a risky, collective and worldly effort. When studying, we do not really know what the exact outcome of our endeavours will be (nor do we desire this). We never study alone. Even when physically alone as students, these individual endeavours always refer to a larger community. We therefore do not study simply for our own benefit (or for a predefined society). What is at stake is the world itself.

Studying comes with an attitude of care and consideration, paying attention to particular issues in our lived reality in a way that obliges us to leave behind already trodden paths; studiers investigate the world and seek knowledge, allowing for exposure and risk, and always in view of something that exceeds personal gain. The studier, in this regard, stands passive in view of something more significant than her own life. The object of study singles out the studier, rather than vice versa. If study implies learning, this comes down to learning anew (Schildermans et al., 2019): an openness to becoming deeply transformed by the world being investigated and starting completely anew with it. This is sharply captured in the following comment by Stengers on a famous dictum by Karl Marx: admitting (with the latter) that "[t]he point is to change the world, not to understand it." But she adds "that this implies giving to the world the power to change us, to 'force' our thinking” (Stengers, 2008, p. 57). Studying is thus driven by issues that demand our attention and effort. The willingness to take up this challenge furthermore implies that we can be changed by the world - in utterly unforeseeable and unpredictable ways.

Thus, the object of study is ultimately that which is possible in a given situation - in the strongest sense of newness, that is (Schildermans et al., 2019). Hence, study comes with both love and hope. By love, we mean an orientation towards the here and now, which we truly want to affirm and hence foster (Vlieghe \& Zamojski, 2019). This makes us, as studiers, devote ourselves to something with studious zeal and effort. Next, hope is required, as we must somehow assume that there is no necessity in the given situation and that we can come up with new ideas and concrete responses that are not disciplined by set parameters - i.e., the knowledge and solutions we already have at our disposal and which make some outcomes probable and others improbable. Hope, as - again Stengers (Stengers \& Zournazi, 2002) defines it, consists of thinking possibility against probability.

Concretely, for a world floundering in the face of this unprecedented and unforeseeable (but simultaneously completely immanent) coronavirus crisis, we argue that an affirmative, educational response could consist of developing particular study practices. By this, we do not mean, in the first instance, enhancing the research capacity of the life sciences. There is no point making such an obvious claim. What we do want to suggest is that we render the issue at hand as a real question of how we want to conceive of future life, i.e., of our common lives in and with this world and all its human and non-human inhabitants. Admittedly, this will involve taking stock of and further delving into investigations of the virus per se and how it affects us from a virological point of view. But more importantly, this also implies a truly communal studious effort in thinking about how we want to give shape to our earthly existence in the future. This will therefore necessitate all those affected - not only (medical) experts - being involved, but also that we adopt a more caring attitude towards the world and our common fate, looking for ways in which all of Earth's inhabitants can thrive. Above all, this entails that we do not content ourselves with solutions that suggest themselves as inescapable based on what our best scientific insights propose as the most probable scenarios. What is called for is that we embark upon a studious thought adventure (see Stengers \& Zournazi, 2002), with the truly new on the horizon and fueled by hope in the present, which is characteristic of the educational practice called studying. 


\section{References}

Agamben, G. (1998). Homo sacer. Sovereign power and bare life. (D. Heller-Roazen, Trans.). Stanford University Press. (Original work published in 1995)

Carusi, T., Di Paolantonio, M., Hodgson, N., \& Ramaekers, S. (2020, April 10). Doing academia in “COVID-19 Times”. Dr. Naomi Hodgson. https://drnaomihodgson.wordpress.com/2020/04/10/doing-academia-in-covid-19-times/

Foucault, M. (2004). La naissance de la biopolitique. Cours au Collège de France 1978-1979. Seuil.

Friesen, N. (2020, April 1). 4 weird things that happen when you videoconference. The Conversation. https://theconversation.com/4-weird-things-that-happen-when-you-videoconference-134879

Gibb, R., Redding, D. W., Chin, K. Q., Donnelly, C. A., Blackburn, T. M., Newbold, T., \& Jones, K. E. (2020). Zoonotic host diversity increases in human-dominated ecosystems. Nature, 584(7821), 398-402. https://doi.org/10.1038/s41586-020-2562-8

Hodgson, N., Vlieghe, J., \& Zamojski, P. (2017). Manifesto for a post-critical pedagogy. punctum books.

Ieven, B., \& Overwijk, J. (2020, March 23). We created this beast. The political ecology of COVID-19. EUROZINE. https://www.eurozine.com/we-created-this-beast/\#

Johnson, B. (2020, March 29). Boris Johnson says 'there really is such a thing as society' in self-isolation update [Video]. YouTube. https://www.youtube.com/watch?v=KkUwuYxVmJY

Latour, B. (2017). Facing Gaia: Eight lectures on the new climatic regime. (C. Porter, Trans.). Polity Press. (Original work published 2015)

Latour, B. (2018). Down to earth: Politics in the new climatic regime. (C. Porter, Trans.). Polity Press. (Original work published 2018)

Lewis, T. (2015). On study: Giorgio Agamben and educational potentiality. Routledge.

Masschelein, J., \& Simons, M. (2015). Education in times of fast learning: The future of the school. Ethics and Education, 10(1), 84-95.

Schildermans, H., Simons, M., \& Masschelein, J. (2019). The adventure of study: Thinking with artifices in a Palestinian experimental university. Ethics and Education, 14(2), 184-197.

Stengers, I. (2008). Experimenting with refrains: Subjectivity and the challenge of escaping modern dualism. Subjectivity, 22(1), 38-59. https://doi.org/10.1057/sub.2008.6

Stengers, I., \& Zournazi, M. (2002). A “cosmo-politics”: Risk, hope, change. A conversation with Isabelle Stengers. In M. Zournazi (Ed.), Hope. New philosophies for change (pp. 244-272). Pluto Press.

Swillens, V., \& Vlieghe, J. (2020). Finding soil in an age of climate trouble: Designing a new compass for education with Arendt and Latour. Journal of Philosophy of Education, 54(4), 1019-1031. https://doi.org/10.1111/1467-9752.12462

Tollefson, J. (2020). Why deforestation and extinctions make pandemics more likely. Nature, 584(7820), 175-176. https://doi.org/10.1038/d41586-020-02341-1

Tsing, A. (2015). The mushroom at the end of the world: On the possibility of life in capitalist ruins. Princeton University Press.

Vlieghe, J., \& Zamojski, P. (2019). Towards an ontology of teaching. Thing-centred pedagogy, affirmation and love for the world. Springer. https://doi.org/10.1007/978-3-030-16003-6

\section{Recommended Citation}

Vlieghe, J., \& Zamojski, P. (2020). Earth-bound study as a post-critical response to the corona-crisis. On Education. Journal for Research and Debate, 3(9). https://doi.org/10.17899/on_ed.2020.9.5

\section{About the Author(s)}

Joris Vlieghe is an assistant professor of philosophy and theory of education at KU Leuven (Belgium). With Naomi Hodgson and Piotr Zamojski, he recently published a Manifesto for a Post-Critical Pedagogy (punctum books, 2017) and, with the latter 
author, published Towards an Ontology of Teaching. Thing-Centred Pedagogy, Affirmation and Love for the World (Springer, 2019). In line with his interest in the figure of the teacher and the educational meaning of studying, his current research explores how study practices can offer a response to the issue of how to live well together with the world's human and non-human inhabitants in times of ecological catastrophe. He is also interested in the impact of digital technologies on education and on the future of schooling, especially when the culture of the screen is (rapidly) substituted for the culture of the book.

Piotr Zamojski is an assistant professor of theory of education and didactics at the University of Gdańsk (Poland). With Naomi Hodgson and Joris Vlieghe, he recently published a Manifesto for a Post-Critical Pedagogy (punctum books, 2017) and, with the latter author, published Towards an Ontology of Teaching. Thing-Centred Pedagogy, Affirmation and Love for the World (Springer, 2019). He has also published work on issues associated with the bureaucratization of education, totalitarianism and educational theory, building a public sphere around education, and the role of cultural codes in schooling. 